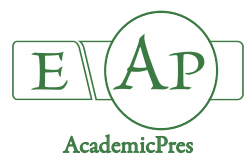

\title{
Effect of Grafting on Tomato Fruit Quality
}

\author{
Dorin SORA ${ }^{1}$, Mădălina DOLTU ${ }^{1 *}$, Elena Maria DRĂGHICI², \\ Marian I. BOGOESCU ${ }^{1}$
}

\author{
${ }^{1}$ Research and Development Institute for Processing and Marketing of Horticultural Products - Horting, $5 N$ Drumul Gilăului Street, District 4 , \\ 041715, Bucharest, Romania; emaflowers7@gmail.com; doltumadalina@yahoo.com (*corresponding author); bogoescumarian@gmail.com \\ ${ }^{2}$ University of Agronomic Sciences and Veterinary Medicine, 59 Mărăşti Boulevard, District 1, 011464, Bucharest, \\ Romania;draghiciem@yahoo.com
}

\begin{abstract}
The study aimed to assess if grafting affects tomato fruit quality. The research has been conducted in greenhouses where grafted and ungrafted tomatoes have been produced. A Romanian tomato hybrid and a Dutch tomato hybrid, 'Siriana' F1 and 'Abellus' F1, were used as scions and four cultivars of the Lycopersicon genus, 'Emperador' F1 (Dutch hybrid), ' $\mathrm{L}_{542}$, ' $\mathrm{L}_{543}$ ' and ' $\mathrm{L}_{544}$ ' (Romanian cultivars) were used as rootstocks. Eight grafted variants ('Siriana' $\times$ 'Emperador', 'Siriana' $\times$ ' $\mathrm{L}_{542}$, 'Siriana' $\times{ }^{\prime} \mathrm{L}_{543}$ ', 'Siriana' $\times \mathrm{L}_{544}$ ', 'Abellus' $\times$ 'Emperador', 'Abellus' $\times{ }^{\prime} \mathrm{L}_{542}$,' 'Abellus' $\times{ }^{\prime} \mathrm{L}_{543}$ ', 'Abellus' $\times{ }^{\prime} \mathrm{L}_{544}$ ') and two ungrafted variants ('Siriana', control and 'Abellus', control) were obtained. The tomato fruit quality has been observed at 'Siriana' and 'Abellus' grafted on all rootstocks. Compared to ungrafted tomatoes, which have yielded $80.1 \%$ and $85.3 \%$ of extra and first quality fruits, 'Siriana' and 'Abellus' grafted on 'Emperador' have had a very good fruit quality, $82.3 \%$ and $86.8 \%$ and grafted on Romanian cultivars have had a quality between $79.1-79.8 \%$ and $84.1-84.4 \%$ to the same quality standards. Analyzing the dependence between the quality categories (extra and first class) and the soluble dry substance content, a positive dependence was observed between grafted plants and ungrafted plants at both hybrids, 'Siriana' $r^{2}=0.4914$ and 'Abellus' $r^{2}=0.1517$ and the carbohydrates content, a negative dependence was observed between grafted plants and ungrafted plants at both hybrids, 'Siriana' $\mathrm{r}^{2}=0.017$ and 'Abellus' $\mathrm{r}^{2}=0.798$. The total vitamin $\mathrm{C}$ content has decreased after grafting. The grafting has had an influence on the soluble dry substance content, the total amount of carbohydrates and vitamin $\mathrm{C}$ at all grafting combinations. It can be said that the rootstocks played an important role on the fruit quality.
\end{abstract}

Keywords: carbohydrates; rootstocks; soluble substance; tomatoes; vitamin C; quality

\section{Introduction}

Tomato (Solanum lycopersicum L.) is one of the most popular vegetable crops in the world. The carbohydrate (2.9-7\%), vitamins (A, B, B2, B6, C), salts of important mineral elements (K, P, Fe, $\mathrm{Ca}, \mathrm{I}, \mathrm{Mg}$ ) and organic acids $(0.5-1.5 \%)$ content of tomato fruits is very important (Lagunovschi-Luchian et al., 2016).

The grafting is a vegetative multiplication method that induces or improves some qualities on fruit production. Grafting on Solanaceae is a similar approach to crop rotation (Blestos et al., 2008), a practice meant to increase productivity, a method which has improved and spread quickly during the past years. This method aimed at producing plants with higher resistance or tolerance to soil diseases (Fusarium and Verticillium) and pests (nematodes), as well as to abiotic factors and at increasing tomato fruit quality and productivity (Hoza et al., 2017; Bogoescu, 2019). Research regarding the effect of grafting on the quality of tomato fruits is important to highlight possible higher values of some parameters compared to the tomato fruits from ungrafted cultures.

Davis et al. (2008) showed discrepant results concerning fruit quality provided by grafted plants, but according to Fernandez-Garci et al. (2004), grafting could be a useful tool to increase tomato fruit quality. There are many conflicting reports on changes in fruit quality due to grafting and whether grafting effects are advantageous or deleterious (Rouphael et al., 2010). The sugars and acid composition of tomato largely determine its flavour quality. High contents of sugars and titratable acids are considered parameters of good taste and flavour (Kader, 2008). Some tomato rootstocks are able to induce significant increases in fruit sugars and titratable acids, but these effects seem to be dependent on both the scion and rootstock genotypes 
(Flores et al., 2010; Rouphael et al., 2010), although grafting for some tomato scion/rootstock combinations can lead to an increased titratable acids and decreased sugars (Schwarz et al., 2013).

Grafting is thus considered an important technique for sustainable greenhouse production of fruit-bearing vegetables; the influence of grafting on the yield of fruitbearing vegetables in Slovenia has not been precisely studied yet (Maršić et al., 2004). Tomato has a direct response to production techniques (Ece et al., 2009).

The purpose of this study has been to show the effect of tomato grafting on fruit quality. The research in the tomato grafting field began at Horting Institute, Bucharest, Romania in 2002 and have continued up to now; research on this subject is evolving.

\section{Materials and Methods}

\section{Biologicalmaterials}

The research was conducted at the Horting Institute, Bucharest, Romania.

The biological material used was a Romanian tomato hybrid ('Siriana' F1), a Dutch tomato hybrid ('Abellus' F1) and four rootstocks, a Dutch tomato hybrid ('Emperador' F1) and three Romanian tomato cultivars (' $\mathrm{L}_{542}$ ', ' $\mathrm{L}_{543}$ ' and ' $\mathrm{L}_{544}$ ') obtained from the Research and Development Station for Vegetable Growing, Buzău, Romania.

This research was implemented in a randomized complete block design with two grafting combinations and the ungrafted control for each cultivar used. 30 plants were used in 3 replications of 10 plants each for every combination and control, in the following experimental scheme (variants): V1 - 'Siriana' $\times$ 'Emperador'; V2 'Siriana' $\times$ 'L $\mathrm{L}_{542}$ '; V3 - 'Siriana' $\times$ ' $\mathrm{L}_{543}$ '; V4 - 'Siriana' $\times$ 'L544; V5 - 'Siriana', control (ungrafted); V6 - 'Abellus' $\times$ 'Emperador'; V7 - 'Abellus' X 'L $L_{42}$; V8 - 'Abellus' $\times$ 'L $L_{543}$ '; V9 - 'Abellus' × 'L544'; V10 - 'Abellus', control (ungrafted).

'Siriana' F1 is a creation from the germplasm bank of Research and Development Station for Vegetable Growing, Buzău, Romania and is tested as grafted and ungrafted plants cultivated in greenhouses at Horting, Institute Bucharest, Romania.

'Siriana' F1 has great vigor, spherical shaped and slightly flattened fruit, red in color, with an up to $150 \mathrm{~g}$ in weight, the height of $5 \mathrm{~cm}$, diameter of $6.5 \mathrm{~cm}$ and $4-5$ seminal lodges.

The plant is early (110-115 days), indeterminate and well adapted to field conditions and protected areas.

'Abellus' F1 (the seed source is the Rijk Zwaan company in the Netherlands) is a Dutch hybrid, very frequently cultivated in Romania and tested as grafted and ungrafted plants cultivated in greenhouses at Horting Institute Bucharest.

'Abellus' F1 has great vigor, spherical shaped and slightly flattened fruit, red in color, with up to $150-180 \mathrm{~g}$ in weight. The plant is early (110-115 days), indeterminate and well adapted to field conditions and protected areas.

'Emperador' F1 (the seed source is the Rijk Zwaan company in the Netherlands) is a very vigorous tomato rootstock which impacts the grafted plant with a harmonious growth. These rootstocks are very resistant to the attack of the nematodes and to Fusarium sp., Verticillium sp. and Tomato Mosaic Virus, recommended for protected areas and field.

' $\mathrm{L}_{542}$ ', ' $\mathrm{L}_{543}$ ' and ' $\mathrm{L}_{544}$ ' are three tomato genotypes obtained by amelioration works performed by some horticultural researchers from VDRS Buzău and tested in experimental fields in the Horting Institute, Bucharest for homologation as rootstocks for tomato grafting.

\section{Producing grafted seedlings}

The grafted and ungrafted seedlings have been produced in a plastic professional greenhouse. This greenhouse is specialized in producing vegetables seedlings; it has a 1,450 $\mathrm{m}^{2}$ surface, it is protected against condensation by a double layers cover with an under pressure air layer as thermal insulator and it is equiped with a system for shadowing, ventilating and cooling the grafting room (Bogoescu et al., 2009).

The technology used for obtaining tomato seedlings was according to the specific technology of solanaceous vegetable grafting.

The seedlings (scions and rootstocks) have been obtained in 70 alveolar plates with a capacity of $50 \mathrm{ml}$ per alveolus, using as substrate a peat with a grain size 0-10 mm, NPK $\left(1 \mathrm{~kg} \mathrm{~m}^{-3}\right)$, microelements B, Mg, Cu, Mn, Zn, Fe, S $\left(0.050 \mathrm{~kg} \mathrm{~m}^{-3}\right)$, calcar $\left(4.7 \mathrm{~kg} \mathrm{~m}^{-3}\right), \mathrm{pH} 6$ and wetting agent $100 \mathrm{ml} \mathrm{m}^{-3}$.

After grafting, seedlings had been managed by following specific technology for producing vegetable seedlings until they were planted in the greenhouse.

\section{Experimental design of grafted and ungrafted tomato culture}

The culture was established during the first ten days of May in the greenhouse, without heating systems, with a metal structure, covered in glass. The planting was made in a density of 20,000 grafted plants per hectare and 27,000 ungrafted plants per hectare.

Tomato culture specific works in protected spaces were applied during the vegetation time. Fruit harvesting started in mid-July to the first decade of September.

\section{Determinations}

The fruits utilized were harvested during maturation phase no. 3 (F3) with 50-70\% pigmentation to pink-red. The tomatoes were sorted into quality categories (extra, first and second) according to calibration scales, from lots for internal market.

The determination of organoleptic changes (aspect, texture and taste) was made by qualifying them ("very good", "good", "acceptable", "mediocre" and "inappropriate"). The tastings were performed for organoleptic appreciation, with tomato fruits with $90-100 \%$ pigmentation to red. Tasting records followed three appreciation criteria (aspect, texture and taste). The criteria rating were made using a scale with 100 points.

Each of the three appreciation criteria has a different weight within the overall notation, depending on its importance, as follows: "aspect" represents 15\%, "texture" $35 \%$ and "taste" 50\%. Five grades were distinguished according to the score given (Table 1). 
1248

\section{Fruit chemical analysis}

The analysis has been performed at Horting Institute, Bucharest using five fruits per variant, harvested at consumer maturity. The soluble dry substance has been determined using the WM-7 digital refractometer with a precision of $\pm 0.1 \%$ by ATAGO. The total carbohydrates amount has been determined by the Bertrand method. The vitamin $\mathrm{C}$ ( $\mathrm{mg} 100 \mathrm{~g}^{-1}$ of the product) has been determined after storage (20 days, in plastic box, hemibiosis conditions, $25^{\circ} \mathrm{C}$ ) using the spectrophotometric method with the measurement of the chloroform color intensity (extraction of ascorbic acid with oxalic acid solution, treatment with indophenol dye extracted into chloroform).

\section{Statistical analysis}

The results obtained have been statistically processed using analysis of variance (ANOVA) and Duncan's post hoc test, the 0.05 significance level. The equations of regression and the correlations coefficients have been calculated for both hybrids to highlight the correlation between the quality categories, extra and first class and dry substance and between the quality categories, extra and first class and total carbohydrates.

\section{Results and Discussion}

\section{Fruits quality}

The highest quality percentage was recorded at V6, the 'Abellus' grafted on 'Emperador' (86.8\%), similar results were recorded at V7, V8, V9, the 'Abellus' grafted on Romanian lines (84.1-84.4\%) and the lowest at V2, the 'Siriana' grafted on ' $\mathrm{L}_{542}$ ' $(79.1 \%)$. The influence of the 'Emperador' rootstock has been visible on the 'Siriana' and 'Abellus' hybrids. It has been observed that for both hybrids grafted on 'Emperador' (V1 and V6), the fruit quality is higher than at control (ungrafted), which demonstrates that tomato grafting is a good method of producing planting material in order to obtain plants with high productive potential. The influence of the grafting on the fruit quality (Extra and first class) is presented in Table 2.

The results about organoleptic determinations (aspect, texture and taste) are presented in Table 3.

The rootstock has influenced the aspect, texture and taste, but the differences were insignificant because all variants had a very good qualification and an organoleptic evaluation (score) between 81.1 and 100 points.

Table 1. Classification of fruit according to score obtained

\begin{tabular}{ccc}
\hline No. & Qualification & Total score \\
\hline 1 & Very good & $80-100$ \\
2 & Good & $60-79$ \\
3 & Acceptable & $40-59$ \\
4 & Mediocre & $20-39$ \\
5 & Inappropriate & $0-19$ \\
\hline
\end{tabular}

Table 2. The influence of the grafting on the quality categories, extra and first class (\%)

\begin{tabular}{|c|c|c|c|}
\hline \multirow[t]{2}{*}{ Scion } & \multirow[t]{2}{*}{ Rootstock } & \multirow[t]{2}{*}{ Variant } & Quality standard (\%) \\
\hline & & & \\
\hline \multirow{5}{*}{ 'Siriana' } & 'Emperador' & V1 & $82.3 \mathrm{a}$ \\
\hline & ' $\mathrm{L}_{542}$ ' & V2 & $79.1 \mathrm{c}$ \\
\hline & ' $\mathrm{L}_{543}$ ' & V3 & $79.2 \mathrm{c}$ \\
\hline & ' $\mathrm{L}_{544}$ ' & V4 & $79.8 \mathrm{c}$ \\
\hline & - & V5, control & $80.1 \mathrm{~b}$ \\
\hline \multirow{5}{*}{ 'Abellus' } & 'Emperador' & V6 & $86.7 \mathrm{a}$ \\
\hline & ' $\mathrm{L}_{542}$ ' & $\mathrm{V} 7$ & $84.3 \mathrm{c}$ \\
\hline & ' $\mathrm{L}_{543}$ ' & V8 & $84.1 \mathrm{c}$ \\
\hline & ' $\mathrm{L}_{544}$ ' & V9 & $84.4 \mathrm{c}$ \\
\hline & - & V10, control & $85.3 \mathrm{~b}$ \\
\hline \multirow{2}{*}{ Average } & \multicolumn{2}{|c|}{ grafted } & $82.5 \mathbf{b}$ \\
\hline & \multicolumn{2}{|c|}{ ungrafted } & $82.7 \mathbf{a}$ \\
\hline
\end{tabular}

Table 3. Organoleptic determinations on tomato (aspect, texture and taste)

\begin{tabular}{|c|c|c|c|c|c|c|}
\hline \multirow{2}{*}{ Hybrid } & \multirow{2}{*}{ Variant } & \multicolumn{4}{|c|}{ Organoleptic evaluation (score) } & \multirow{2}{*}{ Qualifying } \\
\hline & & Aspect & Texture & Taste & Total & \\
\hline \multirow{5}{*}{ 'Siriana' } & V1 & 15 & 35 & 50 & 100 & very good \\
\hline & $\mathrm{V} 2$ & 12.2 & 34.48 & 34.36 & 81.04 & very good \\
\hline & V3 & 13.35 & 34.58 & 35.7 & 83.63 & very good \\
\hline & V4 & 13.42 & 34.62 & 40.28 & 88.32 & very good \\
\hline & V5, control & 14.9 & 34.90 & 50 & 99.8 & very good \\
\hline \multirow{5}{*}{ 'Abellus' } & V6 & 15 & 35.00 & 50 & 100 & very good \\
\hline & V7 & 13.22 & 35.10 & 35.22 & 83.54 & very good \\
\hline & V8 & 13.52 & 35.22 & 37.12 & 85.86 & very good \\
\hline & V9 & 13.39 & 35.27 & 40.33 & 88.99 & very good \\
\hline & V10, control & 14.7 & 34.92 & 45.98 & 95.6 & very good \\
\hline
\end{tabular}




\section{Substance content}

The content of soluble dry substance and carbohydrates in fruits was similar for grafted and ungrafted tomatoes (Table 4). It has been observed that fruits produced from grafted 'Abellus' tomatoes on ' $\mathrm{L}_{542}$ ', ' $\mathrm{L}_{543}$ ', 'L $\mathrm{L}_{544}$ ' rootstocks had a slightly higher dry substance content than those from control tomatoes. The carbohydrate content at all rootstocks has been slightly higher in fruits produced from grafted plants compared to the ungrafted plants.

Fruit quality, measured in terms of dry matter, concentration of soluble solids and total sugar content was lower in the fruits of grafted plants than in ungrafted ones, titratable acid content was improved by grafting (Turhan $e t$ al., 2011). The obtained results allow concluding that some grafted tomatoes had a superior production, a superior quantity, but the fruit quality did not change significantly compared to ungrafted tomatoes (control) (Doltu et al., 2017).

Analyzing the dependence between the quality categories (extra and first class) and the soluble dry substance content, a positive dependence was observed between grafted plants and ungrafted plants at both hybrids, 'Siriana' $r^{2}=0.4914$ and 'Abellus' $r^{2}=0.1517$ (Fig. 1).

The results on grafted tomatoes from Mourao et al. (2017) show that grafting has not affected the fruit quality assessed through firmness, soluble solids and dry mater content. Between the quality categories (extra and first class) and the total carbohydrate content, the coefficient of determination was negative between grafted plants and ungrafted plants at both hybrids, 'Siriana' $\mathrm{r}^{2}=0.017$ and 'Abellus' ${ }^{2}=0.798$ (Fig. 2).
The content of vitamin $\mathrm{C}$ in the ungrafted tomatoes (control) had slightly higher vitamin C content $(39.35 \mathrm{mg}$, $39.39 \mathrm{mg}$ ) than those from the 'Siriana' and 'Abellus' grafted tomatoes (37.92-38.42 mg) (Fig. 3).

Analyzing the influence of rootstock on the quality categories of the grafted tomatoes revealed that the Dutch rootstock used ('Emperador') had a positive influence. The extra and first fruit percentage was between $82.3 \%$ ('Siriana') and $86.7 \%$ ('Abellus') at grafting on 'Emperador' and 79.1-79.8\% ('Siriana') and $84.1-84.3 \%$ ('Abellus') at grafting on Romanian lines compared to $80.1 \%$ ('Siriana', control) and $85.3 \%$ ('Abellus', control). A good compatibility is between scions and the 'Emperador' rootstock. The fruit quality has been influenced positively ('Emperador') and negatively (Romanian rootstocks) by grafting. Grafting increased the marketable and total yield, while differences in marketable and total fruit number were lower (Moreno et al., 2019).

The rootstock has influenced the aspect, texture and taste, but with insignificant differences because all variants had a very good qualification and an organoleptic evaluation (score) between 81.1 and 100 points.

The fruit content of soluble dry substance was similar for grafted and ungrafted tomatoes. It has been noticed that the fruits produced from the 'Abellus' tomatoes grafted on Romanian rootstocks had slightly higher dry substance content than those from control tomatoes. They were followed by the 'Abellus' control tomatoes grafted on Dutch rootstocks, compared with the fruits produced from 'Siriana' control tomatoes, which had a slightly higher dry matter content than those from grafted tomatoes.

Table 4. Soluble dry substance and total carbohydrate content from tomato fruits

\begin{tabular}{|c|c|c|c|}
\hline Hybrid & Variant & Soluble dry substance (\%) & Total carbohydrates (\%) \\
\hline \multirow{5}{*}{ 'Siriana' } & V1 & $4.1 \mathrm{~b}$ & $3.1 \mathrm{~b}$ \\
\hline & $\mathrm{V} 2$ & $4.1 \mathrm{~b}$ & $3.5 \mathrm{a}$ \\
\hline & V3 & $4.1 \mathrm{~b}$ & $3.5 \mathrm{a}$ \\
\hline & V4 & $4,1 \mathrm{~b}$ & $3,5 \mathrm{a}$ \\
\hline & V5, control & $5.3 \mathrm{a}$ & $2.8 \mathrm{c}$ \\
\hline \multirow{5}{*}{ 'Abellus' } & V6 & $3.6 \mathrm{c}$ & $3.2 \mathrm{~b}$ \\
\hline & $\mathrm{V} 7$ & $5.1 \mathrm{a}$ & $3.1 \mathrm{a}$ \\
\hline & V8 & $5.1 \mathrm{a}$ & $3.1 \mathrm{a}$ \\
\hline & V9 & $5.1 \mathrm{a}$ & $3 a$ \\
\hline & V10, control & $4.4 \mathrm{~b}$ & $2.7 \mathrm{c}$ \\
\hline
\end{tabular}

Different letters between variants denote significant differences (Duncan test, $\mathrm{p}<0.05$ )
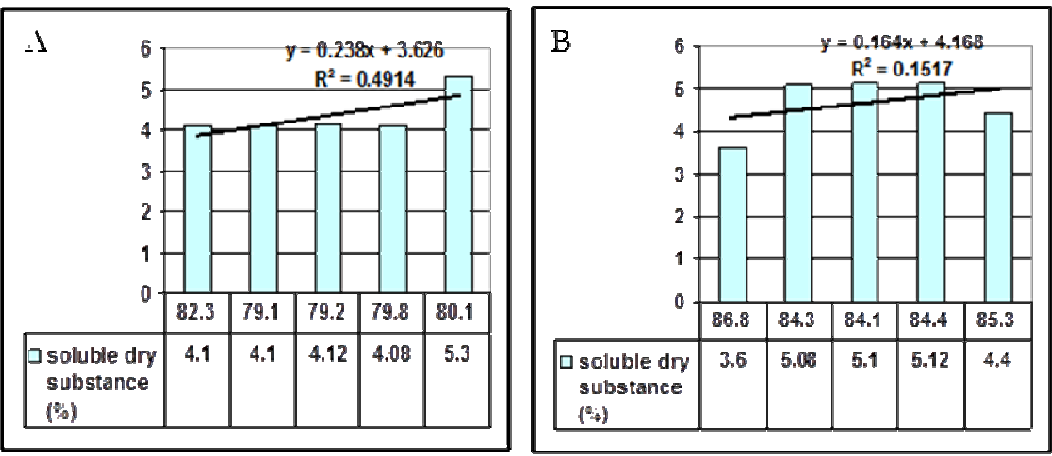

Fig. 1. The regression equation between quality categories (extra and first class) and dry substance content: A - 'Siriana' and B 'Abellus' 

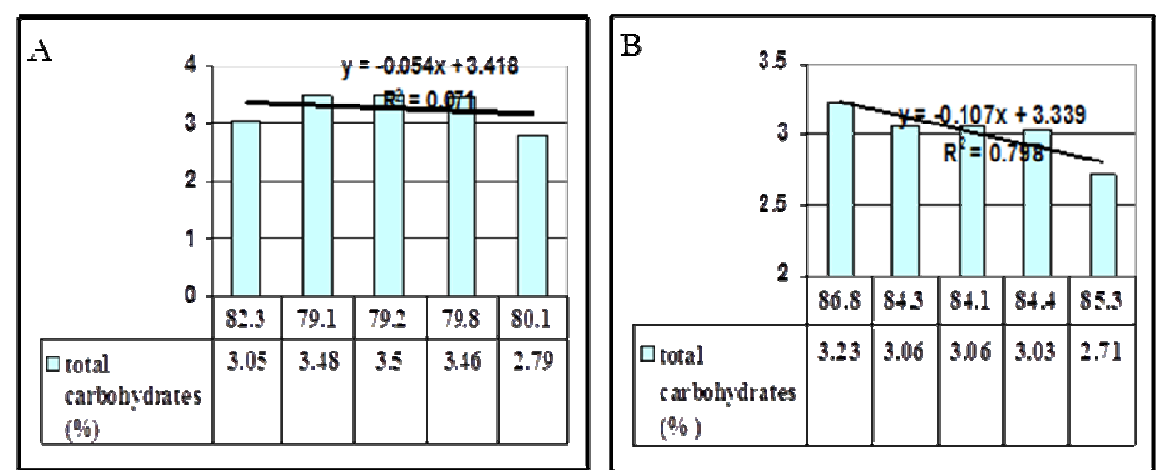

Fig. 2. The regression equation between quality categories (extra and first class) and total carbohydrates: A - 'Siriana' and B 'Abellus'

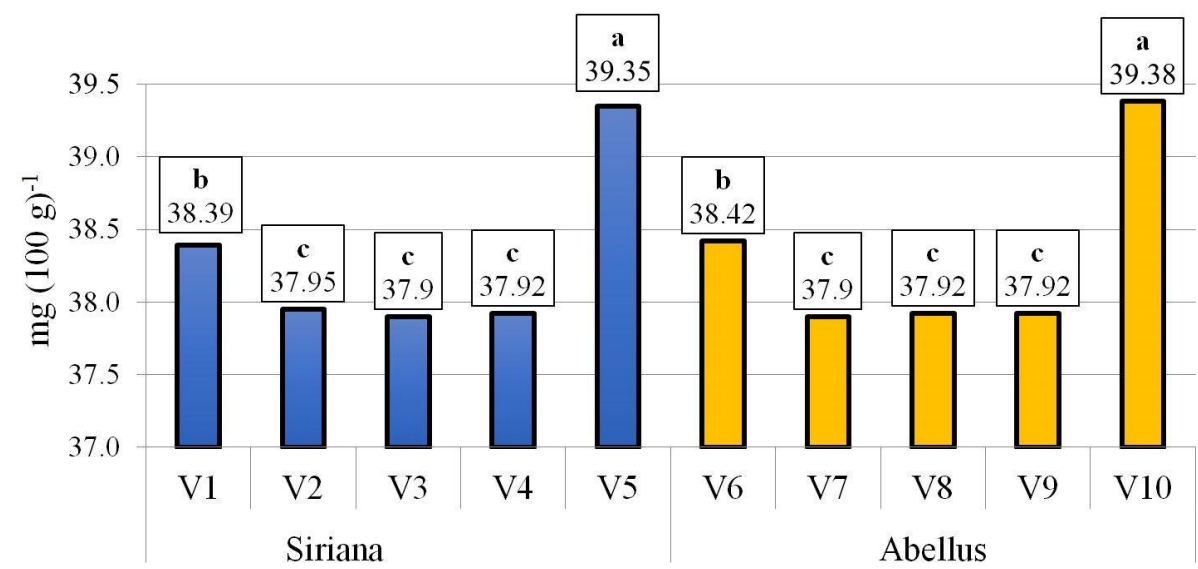

Fig. 3. The influence of grafting on the vitamin $\mathrm{C}$ content. Different letters between variants denote significant differences (Duncan test, $\mathrm{p}<0.05$ )

The fruit content of total carbohydrates was similar at grafted and ungrafted tomatoes. It has been noted that fruits produced from grafted tomatoes on Dutch and Romanian rootstocks had slightly more total carbohydrate content than those from control tomatoes at both scions ('Siriana' and 'Abellus'). The content of vitamin $\mathrm{C}$ in the ungrafted tomatoes (control) had slightly higher vitamin $\mathrm{C}$ content than those from the 'Siriana' and 'Abellus' grafted tomatoes.

The content of total vitamin C significantly decreased after grafting (Vinkovic Vrcek et al., 2011). Savvas et al. (2011) showed that fruit quality characteristics were not affected by grafting or the rootstock genotype. Tomato variety and harvest maturity of fruit were the main factors affecting nutritional value of tomatoes (Erba et al., 2013). Fruits harvested from grafted plants had higher firmness than those harvested from nongrafted plants without affecting the content of soluble solids (Huitrón-Ramírez et al., 2009). Concerns that grafting might contribute to inferior fruit quality $(\mathrm{pH}$, titratable acidity, total soluble solids, lycopene, vitamin C, firmness, "taste") seem unfounded in general, though isolated cases show dramatic differences (Grieneisen et al., 2018). The physiological mechanisms at play which mediate rootstock effects on scion performance are discussed in interpreting the implications of grafting for the configuration of vegetable fruit physicochemical quality and nutritive value (Kyriacon et al., 2017).

\section{Conclusions}

In conclusion, the use grafted tomato plants, the grafting combinations (scions $\mathrm{x}$ rootstocks) researched in this experiment, may be recommended for greenhouse cropping.

Based on the above mentioned results, it can be said that the rootstocks played a important role in fruit quality.

The results showed that tomato grafting on the suitable rootstock ('Emperador') has positive effects on the nutritional quality of fruits compared with the ungrafted tomatoes and the tomatoes grafted on others rootstocks ('L542', 'L543' and 'L544').

\section{Conflict of Interest}

The authors declare that there are no conflicts of interest related to this article. 


\section{References}

Blestos FA, Olympos CM (2008). Rootstocks and grafting of tomatoes, peppers and eggplants for soil-borne disease resistance, improved yield and quality. The European Journal of Plant Science and Biotechnology 2(1):62-73.

Bogoescu M (2019). Grafting eggplant as a control method of soilborne pathogens and nematodes. Acta Horticulturae 1249:17-22.

Bogoescu M, Doltu M, Sora D, Mohora A, Iordache B (2009). Results on establishing the technology for obtaining the watermelons grafted seedlings. Bulletin UASVM Cluj-Napoca. Horticulture 66(1):397-403.

Davis AR, Perkins-Veazie P, Hassell R, King SR, Zhang X (2008). Grafting effects on vegetable quality. HortScience 43:1670-1672.

Doltu M, Bogoescu M, Sora D, Șovărel G (2017). Impact of some rootstocks on tomato production. Nano, bio, green and space - technologies for a sustainable. Advances in Biotechnology 17:251-256.

Ece A, Darakci N (2009). Effect of number of different stems on some fruit quality characteristics and yield in tomatoes (Lycopersicon lycopersicum L.).Journal of Applied Biological Sciences 3(2):175-178.

Erba D, Casiraghi MC, Ribas-Agustí A, Cáceres R, Marfà O, Castellari M (2013). Nutritional value of tomatoes (Solanum lycopersicum L.) grown in greenhouse by different agronomic techniques. Journal of Food Composition and Analysis 31(2):245-251.

Fernandez-Garci N, Martinez V, Cerda A, Carvajal M (2004). Fruit quality of grafted tomato plants grown under saline conditions. The Journal of Horticultural Science and Biotechnology 79(6):995-1001.

Flores FB, Sanchez-Bel P, Estan MT, Martinez-Rodriguez MM, Moyano E, Morales B, ... Bolarin MC (2010). The effectiveness of grafting to improve tomato fruit quality. Scientia Horticulturae 125:211-217.

Grieneisen ML, Aegerter BJ, Stoddard CS, Zhang M (2018). Yield and fruit quality of grafted tomatoes, and their potential for soil fumigant use reduction. A meta-analysis. Agronomy for Sustainable Development 38(3):1-16.

Hoza G, Doltu M, Dinu M, Becherescu AD, Apahidean AI, Bogoescu MI (2017). Response of different grafted eggplants in protected culture. Notulae Botanicae Horti Agrobotanici Cluj-Napoca 45(2):473-480.

Huitrón-Ramírez MV, Ricárdez-Salinas M, Camacho-Ferre F (2009). Influence of grafted watermelon plant density on yield and quality in soil infested with melon necrotic spot virus. HortScience 44(7):1838-1841.
Kader AA (2008). Flavor quality of fruits and vegetables. Journal of the Science of Food and Agriculture 88:1863-1868.

Kyriacou MC, Rouphael Y, Colla G, Zrenner R, Schwarz D (2017). Vegetable grafting: The implications of a growing agronomic imperative for vegetable fruit quality and nutritive value. Frontiers in Plant Science $8(741): 1-23$.

Lagunovschi-Luchian V, Vînătoru C (2016). Legumicultură. Ed. Alpha MDN.

Maršić NK, Osvald J (2004). The influence of grafting on yield of two tomato cultivars (Lycopersicon esculentum Mill.) grown in a plastic house. Acta Agriculturae Slovenica 83(2):243-249.

Moreno MM, Villena J, González-Mora S, Moreno C (2019). Response of healthy local tomato (Solanum lycopersicum L.) populations to grafting in organic farming. Scientific Reports 9(1):4592.

Mourao I, Brito ML, Moura L, Ferreira EM, Costa RS (2017). The effect of pruning systems on yield and fruit quality of grafted tomato. Horticultura Brasileira35(2):247-251.

Rouphael Y, Schwarz D, Krumbein A, Colla G (2010). Impact of grafting on product quality of fruit vegetables. Scientia Horticulturae 127(2):172-179.

Savvas D, Savva A, Ntatsi G, Ropokis A, Karapanos I, Krumbein A, Olympios C (2011). Effects of three commercial rootstocks on mineral nutrition, fruit yield and quality in salinised tomatoes. Journal of Plant Nutrition and Soil Science 174(1):154162.

Schwarz D, Ożtekin GB, Tüzel Y, Brückner B, Krumbein A (2013). Rootstocks can enhance tomato growth and quality characteristics at low potassium supply. Scientia Horticulturae 149:70-79.

Turhan A, Ozmen N, Serbeci MS, Seniz V (2011). Effects of grafting on different rootstocks on tomato fruit yield and quality. Horticultural Science 38(4):142-149.

Vinkovic Vrcek I, Samobor V, Bojic M, Medic-Saric M, Vukobratovic M, Erhatic R, ... Matotan Z (2011). The effect of grafting on the antioxidant properties of tomato (Solanum lycopersicum L.). Spanish Journal of Agricultural Research 9(3):844851. 